\title{
Approaches to multidrug-resistant organism prevention and control in long-term care facilities for older people: a systematic review and meta-analysis
}

Valerie Wing Yu Wong ${ }^{1}$, Ying Huang ${ }^{1}$, Wan In Wei ${ }^{1}$, Samuel Yeung Shan Wong ${ }^{1}$ and Kin On Kwok ${ }^{1,2,3,4^{*}}$ (1)

\begin{abstract}
Background: Despite clear evidence of benefits in acute-care hospitals, controversy over the effectiveness of IPC measures for MDROs is perceptible and evidence-based practice has not been established.

Objective: To investigate the effects of IPC interventions on MDRO colonization and infections in LTCFs.

Data sources: Ovid MEDLINE, EMBASE, and CINAHL from inception to September 2020.

Eligibility criteria: Original and peer-reviewed articles examining the post-intervention effects on MDRO colonization and infections in LTCFs.

Interventions: (i) Horizontal interventions: administrative engagement, barrier precautions, education, environmental cleaning, hand hygiene, performance improvement, and source control; and (ii) vertical intervention: active surveillance plus decolonization.

Study appraisal and synthesis: We employed a random-effects meta-analysis to estimate the pooled risk ratios (pRRs) for methicillin-resistant Staphylococcus aureus (MRSA) colonization by intervention duration; and conducted subgroup analyses on different intervention components. Study quality was assessed using Cochrane risk of bias tools.

Results: Of 3877 studies identified, 19 were eligible for inclusion (eight randomized controlled trials (RCTs)). Studies reported outcomes associated with MRSA (15 studies), vancomycin-resistant Enterococci (VRE) (four studies), Clostridium difficile (two studies), and Gram-negative bacteria (GNB) (two studies). Eleven studies were included in the metaanalysis. The pRRs were close to unity regardless of intervention duration (long: RR 0.81 [95\% Cl 0.60-1.10]; medium: RR 0.81 [95\% Cl 0.25-2.68]; short: RR 0.95 [95\% Cl 0.53-1.69]). Vertical interventions in studies with a small sample size showed significant reductions in MRSA colonization while horizontal interventions did not. All studies involving active administrative engagement reported reductions. The risk of bias was high in all but two studies.
\end{abstract}

Conclusions: Our meta-analysis did not show any beneficial effects from IPC interventions on MRSA reductions in LTCFs. Our findings highlight that the effectiveness of interventions in these facilities is likely conditional on resource

\footnotetext{
*Correspondence: kkokwok@cuhk.edu.hk

1 JC School of Public Health and Primary Care, The Chinese University of Hong Kong, Room 419, 4/F, JC School of Public Health and Primary Care Building, Prince of Wales Hospital, Shatin, N.T., Hong Kong Special Administrative Region, China

Full list of author information is available at the end of the article
}

(c) The Author(s) 2022. Open Access This article is licensed under a Creative Commons Attribution 4.0 International License, which permits use, sharing, adaptation, distribution and reproduction in any medium or format, as long as you give appropriate credit to the original author(s) and the source, provide a link to the Creative Commons licence, and indicate if changes were made. The images or other third party material in this article are included in the article's Creative Commons licence, unless indicated otherwise in a credit line to the material. If material is not included in the article's Creative Commons licence and your intended use is not permitted by statutory regulation or exceeds the permitted use, you will need to obtain permission directly from the copyright holder. To view a copy of this licence, visit http://creativecommons.org/licenses/by/4.0/. The Creative Commons Public Domain Dedication waiver (http://creativeco mmons.org/publicdomain/zero/1.0/) applies to the data made available in this article, unless otherwise stated in a credit line to the data. 
availability - particularly decolonization and barrier precautions, due to their potential adverse events and uncertain effectiveness. Hence, administrative engagement is crucial for all effective IPC programmes. LTCFs should consider a pragmatic approach to reinforce standard precautions as routine practice and implement barrier precautions and decolonization to outbreak responses only.

Keywords: Antimicrobial resistant, Antibiotic resistant, Multidrug-resistant, Methicillin resistant, Infection control, Infection prevention, Barrier precautions, Contact precautions, Nursing homes, Long-term care

\section{Introduction}

The emergence of multidrug-resistant organisms (MDRO) is a major public health concern in the twentyfirst century [1]. It limits the effective antimicrobial treatment options for infections and increases the morbidity, mortality, and health care costs in health care settings worldwide [2-4].

Long-term care facilities for older people (short for "LTCFs") play an important and unique role in MDRO transmission. They have long been regarded as reservoirs for antimicrobial resistance (AMR). Prevalence studies reported approximately three out of ten residents were colonized with methicillin-resistant Staphylococcus aureus (MRSA) [5-7]. Risk factors for MDRO colonization and acquisition have been well characterized [8]. The high colonization prevalence can be attributable to (i) a homelike environment where residents assemble in close proximity, frequently sharing recreation and dining areas, increases the risk of MRSA acquisition $[9,10]$ and (ii) the clustering of vulnerable individuals who are often older, have chronic illnesses, require indwelling or invasive devices and antibiotic use for sustained nursing care [11]. These high-risk individuals have frequent contact with healthcare workers [12]. This contact pattern offers opportunities for onward transmission and acquisition of MDROs, which facilitates intra- and inter-facility transmission [13, 14].

Although research and development of new antibiotics are considered the most direct approach to combat MDROs, financial and technical challenges, such as low profitability yield and lengthy clinical testing may hinder the process [15]. Evidence suggests a significant association between levels of antibiotic consumption and the incidence of antibiotic resistance at both the individual and community levels [16, 17]. As a result, the use of antibiotics alone is not a sustainable solution to avert the current AMR crisis.

Infection prevention and control (IPC) provides an alternative and practical solution to reduce MDRO colonization and prevent harm caused by MDRO infections. This approach comprises two types of interventions: horizontal and vertical. Horizontal interventions aim to control the transmission of multiple pathogens simultaneously by implementing standardized practices, while vertical strategies target a reduction in the transmission of specific pathogens with active screening programmes followed by decolonization [18]. National and local guidelines recommend IPC interventions to control MDRO transmission in LTCFs [19-21]. Both strategies are predominately adopted from acute-care settings or based on a consensus from experts. Recent narrative reviews have described the types of interventions without summarizing the data [22-24]. Studies quantifying intervention effects on MDROs are mostly conducted in acute-care hospitals, which have different contact patterns from LTCFs $[25,26]$. A 2013 Cochrane review attempted to assess the effects of IPC interventions on MDRO transmission in LTCFs [27], but identified only one clustered randomized controlled trial (RCT), and hence could not provide any pooled effect estimates [28]. The RCT reported that interventions improved staff compliance to IPC practice but had no effect on MRSA prevalence among residents. Two other systematic reviews showed contrasting findings in reducing general infection rates in LTCFs $[29,30]$. Lee et al. supported the effectiveness of behavioral change strategies using education, monitoring, and feedback with 17 studies [29], while Uchida's team reported no effect of interventions from 24 articles [30]. Although the number of studies has increased over the years, the evidence has not been updated and remains inconclusive.

In light of this, our systematic review aims to renew the existing evidence and quantify the effects of IPC interventions on MDRO transmission in terms of reductions in colonization and associated infections in LTCFs, and to evaluate the quality of the current evidence.

\section{Methods}

\section{Search strategies and selection criteria}

We searched for studies published from inception to September 2020 with the following electronic databases: "Ovid MEDLINE", "Ovid MEDLINE Epub ahead of print", In-Process \& Other Non-Indexed Citations", "EMBASE", and "CINAHL". A combination of search terms encompassing four domains was developed: MDROs, LTCFs, IPC interventions, and colonization or infections (see Additional file 1). This review conforms to the Preferred Reporting Items for Systematic Reviews and 
Meta-Analyses (PRISMA) guidelines [31]. We include original, peer-reviewed articles that evaluated IPC interventions in LTCFs. Studies assessing IPC interventions during an outbreak (for example, outbreak reports) were excluded. We also excluded qualitative studies, conference papers, posters, commentaries, and review articles.

This review focuses on prevalent and clinically concerned MDROs in LTCFs: MRSA, vancomycin-resistant Enterococci (VRE), multidrug-resistant Gram-negative bacteria (MDR-GNB), those producing extended-spectrum beta-lactamases, and others that are resistant to multiple classes of antimicrobial agents (i.e., carbapenemresistant Enterobacteriaceae (CRE), carbapenemaseproducing Enterobacteriaceae, and Clostridium difficile (C.diff.)) [32].

We defined an LTCF as a public or private residential institution that primarily provides a high level of longterm personal and nursing care assistance to individuals who cannot live independently. Our review included studies specific to LTCFs for older people, but excluded those facilities that provided specialized nursing care to other populations or adopted different care models from LTCFs [33].

We categorized eight IPC interventions into either horizontal or vertical groups. Horizontal interventions included: (i) administrative engagement, (ii) barrier precautions, (iii) education, (iv) environmental cleaning, (v) hand hygiene, (vi) performance improvement, and (vii) source control; vertical interventions included decolonization of colonized subjects only. We described each IPC intervention in detail in an additional table (see Additional file 2).

The primary outcome was MRSA colonization amongst residents in our study settings, where colonization referred to bacteria multiplication in the body without causing any infection. The microbiological assessment indicated the culture positivity in specimens from colonized individuals. We counted multiple positive cultures from the same resident as one colonization episode. "Acquisition" was interpreted as synonymous with "colonization". The secondary outcomes were colonization from other MDROs and all MDRO infections.

\section{Data extraction and quality assessment}

Two authors (VW, YH) independently extracted data and assessed study quality. They identified the articles and subsequently screened them through the full-text papers. Three categories of data were extracted: study characteristics, methodologies, and measured outcomes. The reference lists of relevant review articles from the search were screened for additional studies. We excluded any extended studies in the meta-analysis to avoid duplicate data.
The study quality was assessed using the revised Cochrane risk-of-bias tool (ROB2) for RCTs [34], and the Cochrane Risk of Bias In Non-randomized Studies of Interventions (ROBINS-I) tool for non-randomized studies [35]. The risk of bias of each study was graded as high, with some concerns, and low in ROBs. Similarly, it was graded as serious, moderate, and low in ROBINS-I. The risk-of-bias visualization tool synthesized the assessment and presented the data in a plot [36].

Any disagreements in data extraction and quality assessment were resolved by consensus between VW and $\mathrm{YH}$ or through consultation with a third reviewer (KOK).

\section{Statistical analysis}

Meta-analyses were performed using a random-effects model to estimate the pooled risk ratios (pRRs) with 95\% confidence intervals (CIs). Meta-analyses on MRSA colonization based on 11 articles were conducted. We are limited to perform narrative syntheses on other outcomes due to three studies addressing the outcomes of interest and inconsistent outcome definitions or assessment methods for pooled analysis. In addition to visual inspection of forest plots, we quantified the heterogeneity across studies using the $\mathrm{I}^{2}$-statistics. Contour-enhanced funnel plot and Egger's test were used to evaluate the publication bias-particularly small-study effects [37, 38]. However, the tests were not conducted for subgroup meta-analyses with fewer than ten studies, as the power of the tests would be too low to differentiate chance from real asymmetry [39].

Previous studies suggested that the effects of interventions varied by intervention duration [40, 41]. Subgroup analyses by short- (less than five months), medium(6-11 months), and long- (12 months or longer) duration were conducted. We further summarized pRRs by different combinations of interventions for studies reporting a long duration. Finally, post hoc sensitivity analyses were performed only on studies with concurrent control to assess the robustness of the results.

The package "metaphor" of R Studio version 4.0.2 was used to perform the meta-analyses and subgroup statistical analyses [42, 43]. A p-value of less than 0.05 was considered statistically significant.

\section{Results}

\section{Record retrieval}

The search strategy identified 3877 articles. Following the removal of duplicates, 2776 articles remained. After screening titles and abstracts, 129 articles were included for full-text review (Fig. 1). Nineteen articles met the inclusion criteria and were included in the systematic review [28, 44-61]. 

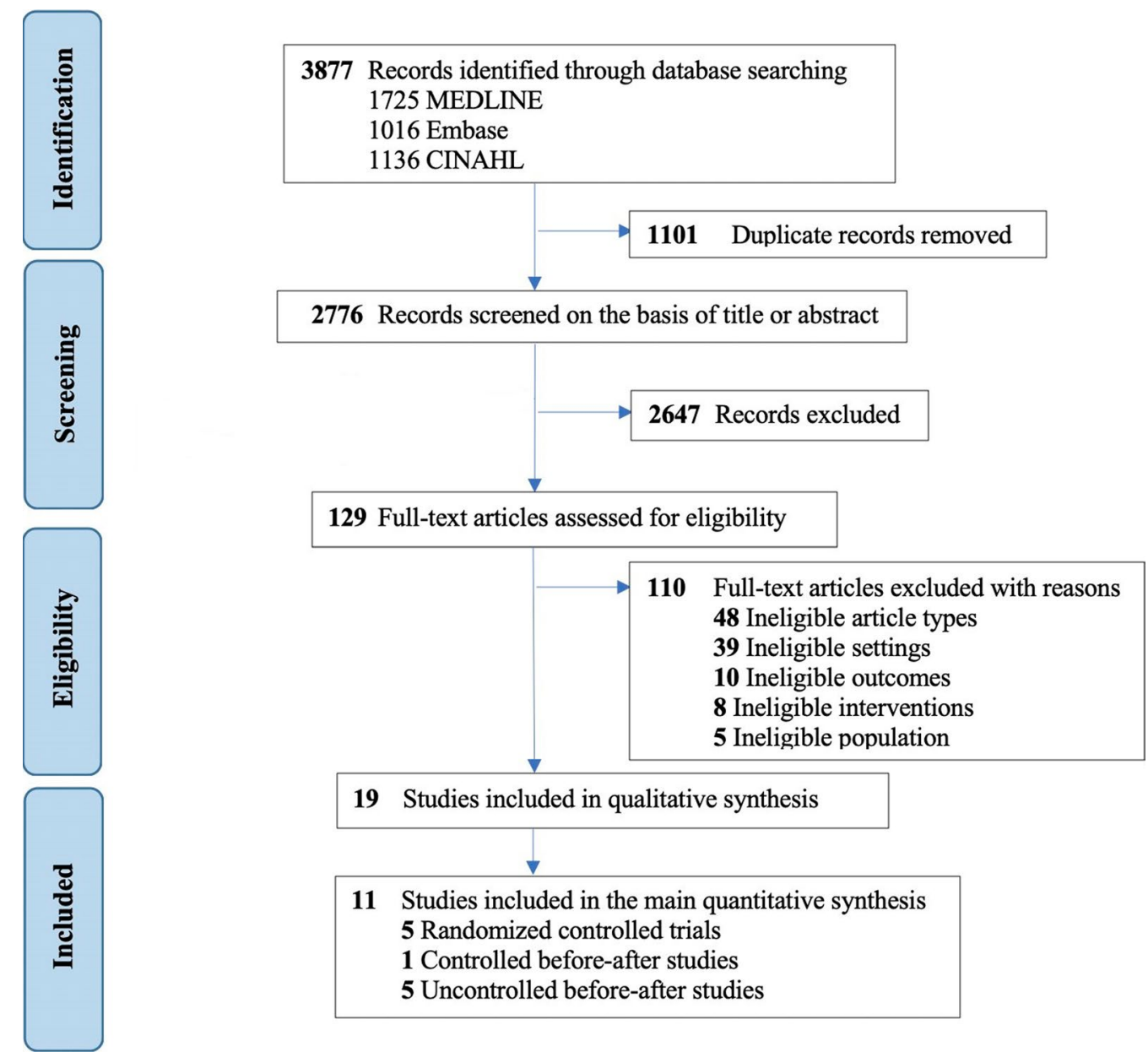

19 Studies included in qualitative synthesis

11 Studies included in the main quantitative synthesis 5 Randomized controlled trials 1 Controlled before-after studies 5 Uncontrolled before-after studies

Fig. 1 PRISMA flow diagram

\section{Characteristics of included studies}

Among the 19 articles included, there were eight RCTs $[28,44,47-49,53,56,57]$, eight uncontrolled before-after studies [45, 46, 50-52, 55, 59, 60], one controlled beforeafter study [54], and two interrupted time-series studies $[58,61]$. One article was an extended study of another $[44,48]$. Two articles were based on the same study but presented different outcomes [56, 57]. Fifteen studies associated with MRSA [28, 44, 46-54, 56, 57, 60, 61], four with VRE $[53,55,58,61]$, two with C.diff. [58, 59], and two with GNB $[45,53]$. Seventeen studies evaluated multifaceted interventions [28, 44-51, 53, 55-61], and two employed a single-component intervention [52, 54]. Twelve studies were conducted in the United States [46, 51-61], four in Europe [28, 44, 48, 50], two in Asia [47, 49], and one in the Middle East [45] (Table 1).

\section{Effectiveness of IPC interventions on MRSA colonization}

Of the 12 studies on MRSA colonization, the directions of intervention effects were divided: half of the studies found insignificant or no effects [28, 44, 47, 48, 50, 54], while the other half reported significant reductions [46, $51-53,57,60]$. Seven studies involved at least three intervention components $[44,46-48,51,53,57]$. The most common interventions were education $(83 \%)[28,44,46-$ $48,50,51,53,57,60]$, decolonization (50\%) [44, 46, 48, $51,52,57]$, and environmental cleaning $(42 \%)[44,46-48$, 57] (Fig. 2). The interventions included in each study are summarized in a table (see Additional file 3). Two studies evaluated the individual effect of barrier precautions and decolonization. One study showed that barrier precautions alone did not affect MRSA acquisition after controlling for patient demographics, comorbidity, and year of admission (odds ratio, 0.97 [95\% CI 0.85-1.12]; $\mathrm{p}=0.71$ ) [54], while the other reported decolonizing both the nasal cavities (nares) and wounds yielded a reduction in mean monthly colonization rate from $22.7 \%$ to $11.5 \%$ $(p=0.0001)$ [52]. Only four studies reported change in compliance followed by the interventions: three on hand hygiene [28, 47, 50], and one on barrier precautions [53]. 
Table 1 Characteristics of included studies

\begin{tabular}{|c|c|c|c|c|c|c|c|c|c|}
\hline References & Country & $\begin{array}{l}\text { Study } \\
\text { design }\end{array}$ & $\begin{array}{l}\text { Control } \\
\text { type }\end{array}$ & $\begin{array}{l}\text { MDRO } \\
\text { type }\end{array}$ & $\begin{array}{l}\text { Measured } \\
\text { outcomes }\end{array}$ & $\begin{array}{l}\text { Staff } \\
\text { compliance } \\
\text { measured }\end{array}$ & $\begin{array}{l}\text { Interventions } \\
\text { (duration, months) }\end{array}$ & $\begin{array}{l}\text { No. of } \\
\text { residents } \\
\text { analyzed } \\
\text { (baseline) }\end{array}$ & $\begin{array}{l}\text { Summary } \\
\text { findings }\end{array}$ \\
\hline $\begin{array}{l}\text { Baldwin } \\
\text { et al. [28] }\end{array}$ & $\begin{array}{l}\text { Northern } \\
\text { Ireland }\end{array}$ & $\begin{array}{l}\text { Clustered } \\
\text { RCT }\end{array}$ & Concurrent & MRSA & $\begin{array}{l}\text { Coloniza- } \\
\text { tion }\end{array}$ & Y & $\mathrm{ED}+\mathrm{PI}(3,6,12)$ & 793 & No effect \\
\hline $\begin{array}{l}\text { Bellini et al. } \\
{[44]}\end{array}$ & Switzerland & $\begin{array}{l}\text { Clustered } \\
\text { RCT }\end{array}$ & Concurrent & MRSA & $\begin{array}{l}\text { Coloniza- } \\
\text { tion; infec- } \\
\text { tions }\end{array}$ & N & $\mathrm{DC}+\mathrm{EC}+\mathrm{ED}(12)$ & 4750 & No effect ${ }^{1}$ \\
\hline $\begin{array}{l}\text { Ben-David } \\
\text { et al. [45] }\end{array}$ & Israel & $\begin{array}{l}\text { Uncon- } \\
\text { trolled } \\
\text { before-after }\end{array}$ & Historical & CRE & Acquisition & $\mathrm{N}$ & $\mathrm{AE}+\mathrm{BP}+\mathrm{ED}+\mathrm{PI}(84)$ & $\sim 20000^{2}$ & Reduction $^{3}$ \\
\hline $\begin{array}{l}\text { Bowler et al. } \\
{[46]}\end{array}$ & $\begin{array}{l}\text { United } \\
\text { States }\end{array}$ & $\begin{array}{l}\text { Uncon- } \\
\text { trolled } \\
\text { before-after }\end{array}$ & Historical & MRSA & $\begin{array}{l}\text { Coloniza- } \\
\text { tion }\end{array}$ & $N$ & $\mathrm{DC}+\mathrm{EC}+\mathrm{ED}(13)$ & 687 & Reduction ${ }^{3}$ \\
\hline $\begin{array}{l}\text { Chuang } \\
\text { et al. [47] }\end{array}$ & $\begin{array}{l}\text { Hong Kong } \\
\text { SAR, China }\end{array}$ & $\begin{array}{l}\text { Clustered } \\
\text { RCT }\end{array}$ & Concurrent & MRSA & $\begin{array}{l}\text { Coloniza- } \\
\text { tion }\end{array}$ & Y & $\begin{array}{l}\mathrm{BP}+\mathrm{EC}+\mathrm{ED}+\mathrm{HH}+\mathrm{Pl} \\
(6,9,12,15)\end{array}$ & 2776 & No effect \\
\hline $\begin{array}{l}\text { Hequet } \\
\text { et al. }{ }^{4}[48]\end{array}$ & Switzerland & $\begin{array}{l}\text { Clustered } \\
\text { RCT }\end{array}$ & Concurrent & MRSA & $\begin{array}{l}\text { Coloniza- } \\
\text { tion }\end{array}$ & $N$ & $\mathrm{DC}+\mathrm{EC}+\mathrm{ED}(12,60)$ & NS & No effect \\
\hline $\begin{array}{l}\text { Ho et al. } \\
{[49]}\end{array}$ & $\begin{array}{l}\text { Hong Kong } \\
\text { SAR, China }\end{array}$ & $\begin{array}{l}\text { Clustered } \\
\text { RCT }\end{array}$ & Concurrent & MRSA & Infections & Y & $\mathrm{AE}+\mathrm{ED}+\mathrm{HH}+\mathrm{PI}(4)$ & 2407 & Reduction ${ }^{3}$ \\
\hline $\begin{array}{l}\text { Horner et al. } \\
{[50]}\end{array}$ & $\begin{array}{l}\text { United } \\
\text { Kingdom }\end{array}$ & $\begin{array}{l}\text { Uncon- } \\
\text { trolled } \\
\text { before-after }\end{array}$ & Historical & MRSA & $\begin{array}{l}\text { Coloniza- } \\
\text { tion }\end{array}$ & Y & $\mathrm{ED}+\mathrm{PI}(6,9,12,18,24)$ & $2237^{5}$ & No effect \\
\hline $\begin{array}{l}\text { Jaqua- } \\
\text { Stewart } \\
\text { et al. [51] }\end{array}$ & $\begin{array}{l}\text { United } \\
\text { States }\end{array}$ & $\begin{array}{l}\text { Uncon- } \\
\text { trolled } \\
\text { before-after }\end{array}$ & Historical & MRSA & $\begin{array}{l}\text { Coloniza- } \\
\text { tion; infec- } \\
\text { tions }\end{array}$ & $N$ & $\begin{array}{l}\mathrm{BP}+\mathrm{DC}+\mathrm{ED}+\mathrm{SC}(12 \\
39)\end{array}$ & 42 & Reduction $^{3}$ \\
\hline $\begin{array}{l}\text { Kauffman } \\
\text { et al. [52] }\end{array}$ & $\begin{array}{l}\text { United } \\
\text { States }\end{array}$ & $\begin{array}{l}\text { Uncon- } \\
\text { trolled } \\
\text { before-after }\end{array}$ & Historical & MRSA & $\begin{array}{l}\text { Coloniza- } \\
\text { tion }\end{array}$ & N & $\mathrm{DC}\left(7^{6}, 5^{7}\right)^{8}$ & 321 & Reduction $^{3,9}$ \\
\hline $\begin{array}{l}\text { Mody et al. } \\
{[53]}\end{array}$ & $\begin{array}{l}\text { United } \\
\text { States }\end{array}$ & $\begin{array}{l}\text { Clustered } \\
\text { RCT }\end{array}$ & Concurrent & $\begin{array}{l}\text { MRSA; VRE; } \\
\text { GNB }\end{array}$ & $\begin{array}{l}\text { Coloniza- } \\
\text { tion; infec- } \\
\text { tions }\end{array}$ & $Y^{10}$ & $\mathrm{BP}+\mathrm{ED}+\mathrm{HH}+\mathrm{PI}(24)$ & 418 & Reduction $^{3}$ \\
\hline $\begin{array}{l}\text { Morgan } \\
\text { et al. [54] }\end{array}$ & $\begin{array}{l}\text { United } \\
\text { States }\end{array}$ & $\begin{array}{l}\text { Controlled } \\
\text { before-after }\end{array}$ & Concurrent & MRSA & $\begin{array}{l}\text { Acquisition; } \\
\text { infections }\end{array}$ & $N$ & BP (48) & 75,414 & No effect \\
\hline $\begin{array}{l}\text { Ostrowsky } \\
\text { et al. [55] }\end{array}$ & $\begin{array}{l}\text { United } \\
\text { States }\end{array}$ & $\begin{array}{l}\text { Uncon- } \\
\text { trolled } \\
\text { before-after }\end{array}$ & Historical & VRE & $\begin{array}{l}\text { Coloniza- } \\
\text { tion }\end{array}$ & $Y^{11}$ & $\begin{array}{l}\mathrm{BP}+\mathrm{EC}+\mathrm{ED}+\mathrm{HH}(12 \\
24)\end{array}$ & 5221 & Reduction $^{3}$ \\
\hline $\begin{array}{l}\text { Peterson } \\
\text { et al. }{ }^{12}[56]\end{array}$ & $\begin{array}{l}\text { United } \\
\text { States }\end{array}$ & $\begin{array}{l}\text { Clustered } \\
\text { RCT }\end{array}$ & Concurrent & MRSA & $\begin{array}{l}\text { MRSA } \\
\text { infections }\end{array}$ & $N$ & 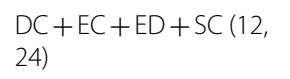 & 7069 & Reduction $^{3}$ \\
\hline $\begin{array}{l}\text { Schora et al. } \\
{[57]}\end{array}$ & $\begin{array}{l}\text { United } \\
\text { States }\end{array}$ & $\begin{array}{l}\text { Clustered } \\
\text { RCT }\end{array}$ & Concurrent & MRSA & $\begin{array}{l}\text { Coloniza- } \\
\text { tion }\end{array}$ & $N$ & $\begin{array}{l}\mathrm{DC}+\mathrm{EC}+\mathrm{ED}+\mathrm{SC}(12, \\
24)\end{array}$ & 4424 & Reduction $^{3}$ \\
\hline $\begin{array}{l}\text { Schweon } \\
\text { et al. [61] }\end{array}$ & $\begin{array}{l}\text { United } \\
\text { States }\end{array}$ & $\begin{array}{l}\text { Uncon- } \\
\text { trolled } \\
\text { interrupted } \\
\text { time series }\end{array}$ & Historical & $\begin{array}{l}\text { MRSA; VRE; } \\
\text { C.diff }\end{array}$ & Infections & Y & $\mathrm{AE}+\mathrm{ED}+\mathrm{HH}+\mathrm{PI}(22)$ & NS & No effect \\
\hline $\begin{array}{l}\text { Silverblatt } \\
\text { et al. [58] }\end{array}$ & $\begin{array}{l}\text { United } \\
\text { States }\end{array}$ & $\begin{array}{l}\text { Uncon- } \\
\text { trolled } \\
\text { interrupted } \\
\text { time series }\end{array}$ & Historical & VRE & $\begin{array}{l}\text { Coloniza- } \\
\text { tion }\end{array}$ & $N$ & $\mathrm{BP}+\mathrm{DC}+\mathrm{ED}+\mathrm{HH}(28)$ & NS & $\begin{array}{l}\text { Absence of } \\
\text { outcome }\end{array}$ \\
\hline $\begin{array}{l}\text { Singh et al. } \\
{[59]}\end{array}$ & $\begin{array}{l}\text { United } \\
\text { States }\end{array}$ & $\begin{array}{l}\text { Uncon- } \\
\text { trolled } \\
\text { before-after }\end{array}$ & Historical & C.diff & $\begin{array}{l}\text { C.diff infec- } \\
\text { tions }\end{array}$ & $N$ & $\begin{array}{l}A E+B P+E C+E D+H H \\
(33)\end{array}$ & $\sim 9381^{13}$ & Reduction $^{3}$ \\
\hline $\begin{array}{l}\text { Thomas } \\
\text { et al. [60] }\end{array}$ & $\begin{array}{l}\text { United } \\
\text { States }\end{array}$ & $\begin{array}{l}\text { Uncon- } \\
\text { trolled } \\
\text { before-after }\end{array}$ & Historical & MRSA & $\begin{array}{l}\text { Coloniza- } \\
\text { tion; MRSA } \\
\text { infections }\end{array}$ & $N$ & $\mathrm{BP}+\mathrm{ED}(3)$ & 164 & Reduction $^{3}$ \\
\hline
\end{tabular}

$\mathrm{AE}$, administrative engagement; $\mathrm{BP}$, barrier precautions; $\mathrm{BSI}$, bloodstream infection; C.diff., Clostridium difficile; $\mathrm{DC}$, decolonization; $\mathrm{ED}$, education; $\mathrm{EC}$, environmental cleaning; GNB, Gram-negative bacteria; HH, hand hygiene; MRSA, methicillin-resistant Staphylococcus aureus; PI, performance improvement; NS, not specified; SC, source control; UC, usual care; VRE, vancomycin-resistant enterococci 
Table 1 (continued)

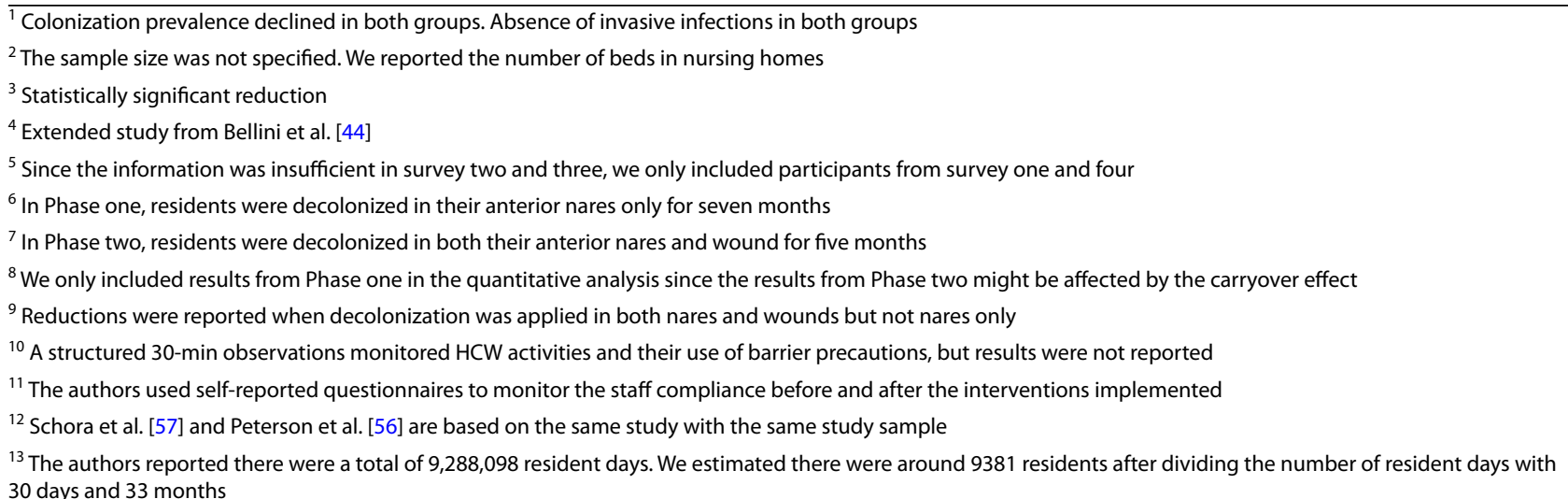

However, the evaluation methods were not standardized (see Additional file 4).

We excluded Hequet et al. (2017) since it is a followup study from Bellini et al. (2015) [44, 48]. Our metaanalysis of 11 articles showed that IPC interventions were not associated with the reduction regardless of the intervention duration (long: pRR 0.81 [95\% CI 0.60-1.10]; medium: pRR 0.81 [95\% CI 0.25-2.68]; short: pRR 0.95 [95\% CI 0.53-1.69]) [28, 44, 46, 47, 50-54, 57, 60]. We present the forest plot for studies evaluating MRSA colonization in an additional figure (see Additional file 5). Neither single-component nor multifaceted interventions resulted in a larger decrease in MRSA colonization (Fig. 3). While active surveillance and decolonization reported reductions, albeit statistically insignificant in larger studies, in colonization (range: pRR 0.34 [95\% CI $0.22-0.53$ ] to 0.88 [95\% CI 0.71-1.10]), interventions involving mainly barrier precautions (range: pRR 1.00 [95\% CI 0.75-1.33] to 1.02 [95\% CI 0.74-1.41]) and education (pRR 1.06 [95\% CI 0.91-1.23]) had no effects on MRSA colonization (Fig. 3). Our findings did not change when the analyses restricted only to studies with concurrent control (long: pRR 0.94 [95\% CI 0.83-1.07]; medium: pRR 1.01 [95\% CI 0.10-10.21]; short: RR 0.96 [95\% CI $0.73-1.26])$. The sensitivity analysis demonstrated a significant drop in the $\mathrm{I}^{2}$ of long-term interventions to $1 \%$ $(\mathrm{p}=0.41)$; the $\mathrm{I}^{2}$ of medium-term interventions reduced only slightly to $77 \%(\mathrm{p}=0.04)$; and, the $\mathrm{I}^{2}$ of short-term interventions remained unchanged at $0 \%$. The forest plot for sensitivity analysis is presented as an additional figure (see Additional file 6).

\section{Effectiveness of IPC interventions on other outcomes}

Three studies employing altogether barrier precautions, hand hygiene, and education reported either reduced VRE colonization or free from new acquisition [53, $55,58]$. Of the two studies reporting reductions, one reported a cluster- and covariate-adjusted hazard ratio (HR) of 0.85 [95\% CI 0.45-1.60] $(\mathrm{p}=0.61)$ [53], while another found a relative risk of 0.30 [95\% CI $0.20-0.70$ ] $(\mathrm{p}=0.001)$ [55]. Two studies which included barrier precautions, education, and performance improvement in their IPC programme found decreases in GNB acquisition. One of them reporting administrative engagement decreased CRE acquisition from 0.5 per 10000 patientdays at baseline to 0.3 per 10000 patient-days two years after implementation [45]. The other study which also included hand hygiene reported an insignificant clusterand covariate-adjusted HR of 0.90 [95\% CI 0.60-1.33] $(p=0.59)$ [53]. There were nine studies evaluating the effects of IPC interventions on infections, of which six reported reduction $[49,51,53,56,59,60]$, one had no infection episodes [44], and two found no effects [54, 61]. The six studies reporting reductions in infections summarized their results in various metrics with two reporting significant rate ratios ranged from 0.54 [95\% CI $0.30-0.97$ ] to 0.61 [95\% CI 0.38-0.97] $(\mathrm{p}=0.04)[49,53]$ and four showing relative reductions in infection rates ranging from $25.9 \%$ to $99.7 \%$ [51, 56, 59, 60]. The rationale for meta-analyses in other outcomes was limited due to heterogeneity in study designs and lack of studies.

\section{Effectiveness of IPC interventions on MDRO outcomes involving administrative engagement}

All studies actively involving the administrations reported reductions in either colonization or infections $[45,49,59,61]$, although one did not reach $5 \%$ significant level [61]. Among the studies that did not result in outcome reductions, both alluded their failures to lack of organizational commitment $[28,47]$.

\section{Study quality}

The risk of bias among 19 studies was generally high (Fig. 4a, b). Of the eight RCTs [28, 44, 47-49, 53, 56, 


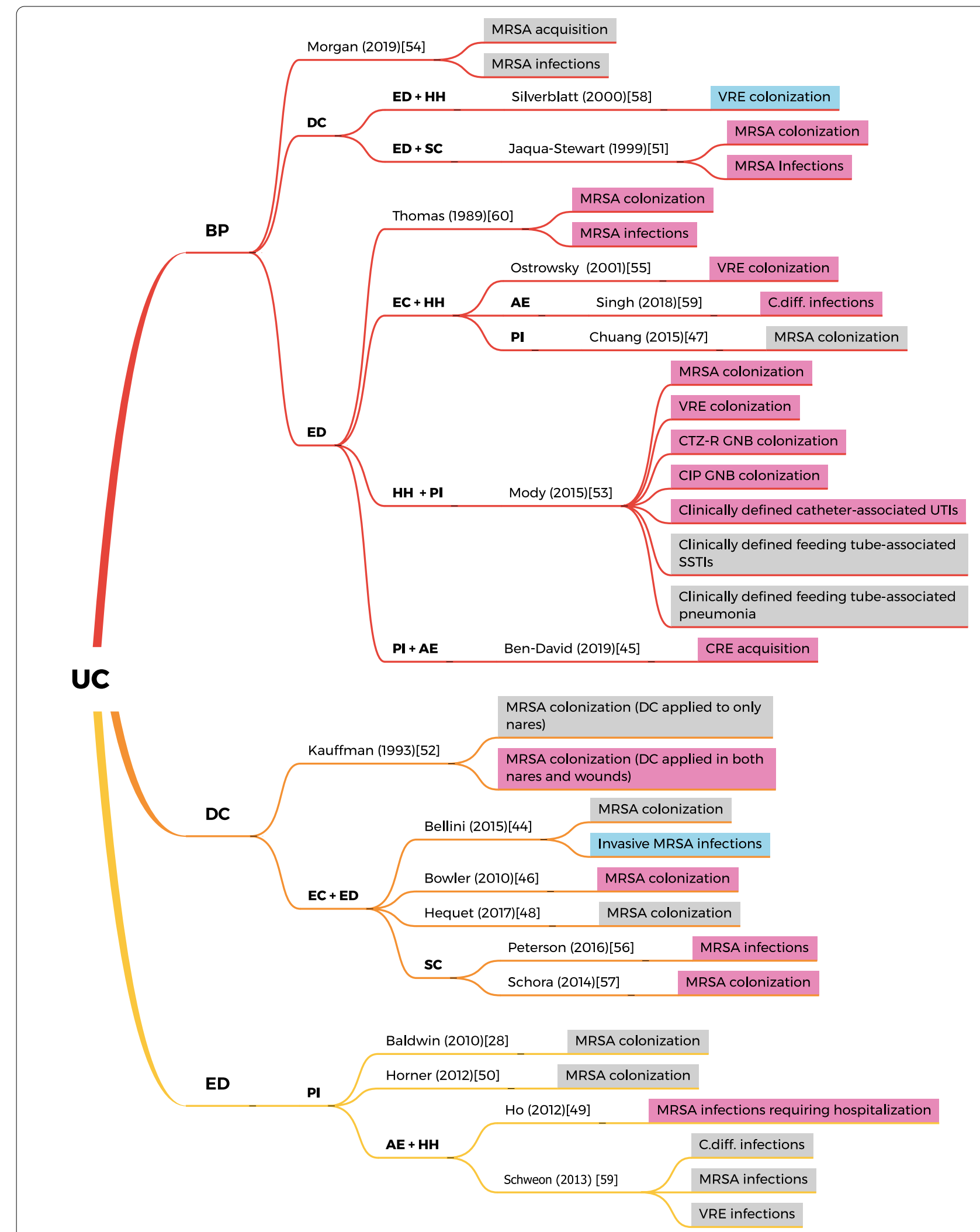

Fig. 2 Components and outcomes of included studies. (Pink—reductions in outcome reported by authors; Grey-no effect in outcome reported by author-Blue, absence of outcome) 


\begin{tabular}{|c|c|c|}
\hline Treatment & $\begin{array}{l}\text { Comparison: other vs 'UC' } \\
\text { (Random Effects Model) }\end{array}$ & $95 \%-\mathrm{Cl}$ \\
\hline $\mathrm{DC}+\mathrm{EC}+\mathrm{ED}$ & $\rightarrow$ & $0.34[0.22 ; 0.53]$ \\
\hline & $\rightarrow$ & $0.41[0.25 ; 0.67]$ \\
\hline $\mathrm{DC}+\mathrm{EC}+\mathrm{ED}+\mathrm{SC}$ & $\rightarrow$ & $0.69[0.50 ; 0.95]$ \\
\hline $\mathrm{DC}+\mathrm{EC}+\mathrm{ED}$ & . & $0.88[0.71 ; 1.10]$ \\
\hline $\mathrm{BP}+\mathrm{EC}+\mathrm{ED}+\mathrm{HH}+\mathrm{PI}$ & & $1.00[0.86 ; 1.16]$ \\
\hline & & $1.00[0.75 ; 1.33]$ \\
\hline $\mathrm{BP}+\mathrm{ED}+\mathrm{HH}+\mathrm{PI}$ & & $1.02[0.74 ; 1.41]$ \\
\hline$E D+P I$ & $T$ & $1.06[0.91 ; 1.23]$ \\
\hline 0.2 & 0.5 & 3 \\
\hline
\end{tabular}

Fig. 3 Forest plot for studies evaluating the long-term intervention effects on MRSA colonization by components. ("DC + EC",

Decolonization and environmental cleaning; "DC", Decolonization only; "DC + EC +ED + SC", Decolonization, environmental cleaning, education, and source control; "DC + EC +ED", Decolonization, environmental cleaning, and education; "BP $+\mathrm{EC}+\mathrm{ED}+\mathrm{HH}+\mathrm{Pl}$ ", Barrier precautions, environmental cleaning, education, hand hygiene, and performance improvement; "BP", Barrier precautions; "BP + ED + HH + Pl", Barrier precautions, education, hand hygiene, and performance improvement; "ED + PI", Education and performance improvement; "UC", Usual care)

57], all but one were at high risk of bias [49]. The only one with "some concerns" of bias reported significant reductions in MRSA infections requiring hospitalization following the implementation of a multimodal strategy [49]. The main reason for downgrading was that most studies did not appropriately adjust for the imbalance of missing outcome data in the analytical stage. The risk of bias assessment using ROB2 tool is presented in an additional table (see Additional file 7). Similarly, we rated the risk of bias of one non-RCTs as "moderate" [50], while others were as "serious" [45, 46, $51,52,54,55,58-61]$. Unadjusted confounders without randomization were the main cause of degradation. The risk of bias assessment using ROBINS-I is available (see Additional file 8). The controlled before-after study with a moderate-level risk of bias reported a small but insignificant increase in MRSA colonization after the implementation of an IPC programme [50].

\section{Publication bias and small study effects}

The funnel plot suggests differences in intervention tendency effects among smaller and larger studies (see Additional file 9). Results from the majority of moderate-sized studies were statistically insignificant but that among studies with a small sample size was generally significant. Small-sized studies with low methodological quality produced exaggerated positive intervention effect estimates. Egger's test also supports the presence of small-study effects (intercept $=-4.05 ; \mathrm{p}=0.03$ ).

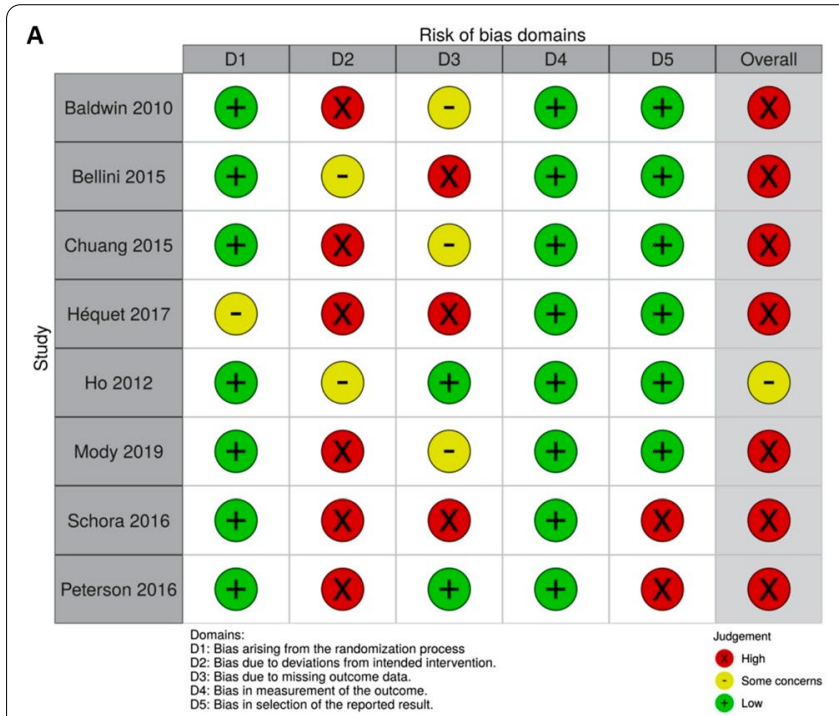

B

B

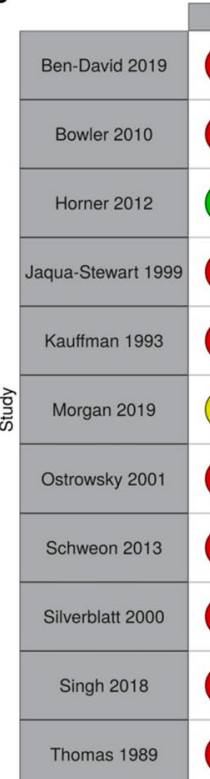
\begin{tabular}{l|l|l} 
Risk of bias domains \\
D1
\end{tabular}

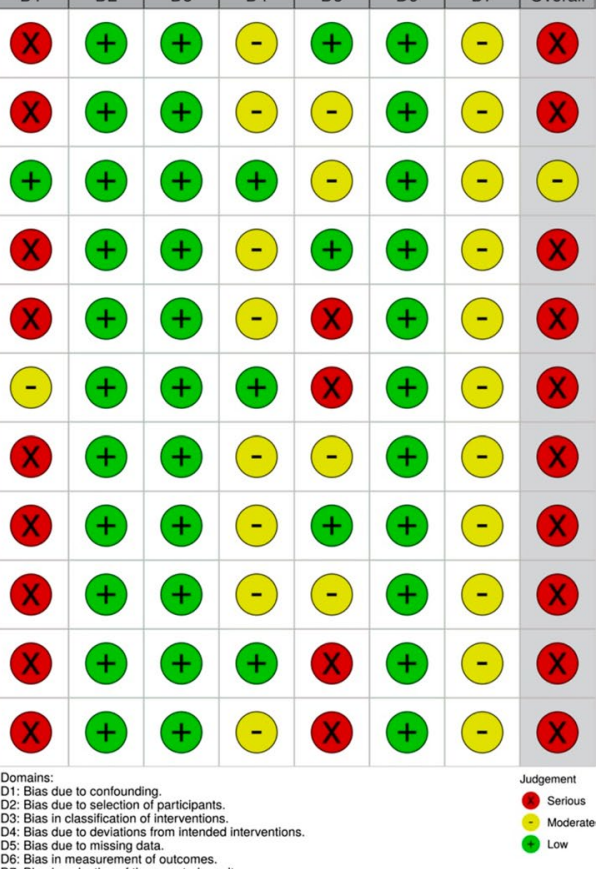

Fig. 4 a Risk of bias plot for randomized controlled trials. b Risk of bias plot for non-randomized studies 


\section{Discussion}

\section{Principal findings}

This systematic review provides an up-to-date, critically appraised, and comprehensive literature syntheses of IPC interventions' effect on MDRO risk in LTCFs. Evidence was overall low in quality. Our meta-analysis did not demonstrate a significant decrease in MRSA colonization following IPC interventions. While the pooled estimates varied by intervention types, none consistently produced significant results of which vertical interventions may reduce MRSA colonization but horizontal interventions had no effects. Some smaller studies with low methodological quality produced exaggerated positive intervention effect estimates. IPC interventions may reduce VRE and GNB colonization while they had an inconsistent impact on MDRO infections. Notably, administrative engagement is a core component in all successful IPC programmes to curtail MDRO colonization in LTCFs.

\section{Comparison with previous literature}

This review adds to the existing knowledge in several ways.

First, this review did not find compelling evidence to support the effectiveness of IPC interventions on MRSA reduction, in particular barrier precautions. Although expert guidance recommends the use of screening and barrier precautions for patients colonized or infected with MDROs, [32, 62, 63], a rising number of studies have questioned their effectiveness and benefits on MDRO control in different health care settings. A large cluster-randomized trial conducted in an intensive care unit found the use of active screening and barrier precautions has been ineffective in reducing transmission of MRSA and VRE [64]. An intervention study in the United States found barrier precautions had no impact on MRSA acquisition and infections [54]. Discontinuing barrier precautions was also not associated with the infection rates surge in a recent meta-analysis [65]. The actual effectiveness of barrier precautions is likely to be conditional on resource availability. In an ideal condition with unlimited resources, i.e., low staff-to-resident ratios, implementing barrier precautions may not necessarily compromise the use of personal protective equipment. However, in low-resource settings like LTCFs, the heavy clinical workload is a major barrier to infection control [66]. In a prospective cohort study, one thousand and thirteen observations were conducted on the adherence of isolation practices among healthcare workers as the burden of isolation increased (20\% or less to greater than $60 \%)$, a substantial decrease in compliance with hand hygiene (from 43.6 to $4.9 \%$ ) and with all five components of contact precautions [67].
While evidence has not yet confirmed the effectiveness, barrier precautions have also been associated with a number of adverse events. Adopting barrier precautions constrains residents' mobility and thus results in social stigma and isolation [9]. A matched-controlled study found that isolation led to medical errors and patient neglect [68]. A systematic review summarized four main adverse outcomes related to barrier precautions: (i) less patient-health care worker contact time, (ii) delays in care and more non-infectious adverse events, (ii) increased patient depression and anxiety symptoms, and (iv) decreased patient satisfaction with care [69]. A survey revealed that isolation increased anxiety of both patients and family members [70]. Barrier precautions also impose burdens to health care workers, which compromises the compliance of hand hygiene and use of personal protective equipment, as the number of isolated patients increases [67]. Overall, the risks of barrier precautions to residents seemed to offset its benefits on MDRO control in LTCFs.

Second, in terms of vertical interventions, although the use of decolonization among patients at risk of infections for a short period was supported [71], its long-term use remains inconclusive. The temporary effect can be attributable to the high rate of recolonization, which is particularly relevant to this unique population in LTCFs. A pilot study conducted in an outpatient chronic haemodialysis unit and an RCT in two LTCFs found the mean recolonization time was 27 and 45 days, respectively [72, 73].

Apart from the temporary effect of decolonization, multiple colonization further complicates the effectiveness of decolonization therapy in LTCFs. Decolonizing a single organism may not be adequate in reducing the risk of transmission. A nested case-control study reported that residents colonized with multidrug-resistant Acinetobacter baumannii were more likely to be colonized with another type of GNB [74]. Besides, decolonization therapy can lead to adverse reactions and increased secondary drug resistance. Of the patients decolonized with mupirocin in an RCT, 25\% developed gastrointestinal adverse reactions, and 5\% progressed into a high level of drug resistance [75]. Therefore, the potential risk of decolonization therapy should be weighed alongside its benefits to MDRO control in LTCFs.

Third, the role of administration has proven to be crucial in various contexts. A few studies suggested the direct and indirect benefits of engaging administrative commitment. A semi-structured interview of 20 clinicians revealed how hospital administrative engagement facilitated interventions in reducing surgical-site infections [76]. Similarly, a Thai national survey described an association between good-to-excellent administrative support and high degree of adherence to environmental 
disinfection [77]. A cross-sectional survey reported that hospitals with more effective leadership showed better compliance in hand hygiene and were less likely to report implementation barriers [78]. The health belief model can be used to explain the association $[79,80]$ : as perceived barriers to action is one of the six key factors that influence health behaviours, a supportive administrative engagement not only eliminates the perceived barriers to implementation but also promotes learning, allocates adequate resources, and creates a facilitative and collaborative environment [81].

Fourth, studies have long demonstrated that interventions designed to improve health outcomes are more effective when implemented in bundles [82]. Over the past decade, multifaceted interventions in IPC have been reported to be more effective in reducing MDRO burden in LTCFs $[29,83]$, and have been widely adopted in national guidelines and recommendations [32, 84]. However, there might be a possible association between the number of interventions and the effectiveness of the programme-a simulation study found synergistic effects of combination interventions for MRSA control in nursing homes, assuming there were no resource constraints [85]. However, after taking cost into account, the more interventions simultaneously employed in the bundle did not correlate with a higher cost-effectiveness than an isolated daily cleaning intervention [86]. The challenge around resource constraints could explain why the number of components did not seem to affect the effectiveness of the programmes in our study.

\section{Strengths and limitations}

This study and its evidence are affected by some inherent limitations. First, in the majority of the studies, very few data on adherence to IPC interventions was reported. However, the compliance of health care workers to interventions greatly influences the assessment of their effectiveness. A low level of adherence would potentially shrink the estimates of the intervention effects towards the null. However, poor compliance to IPC interventions, particularly hand hygiene, is a persistent problem in infection control practice. Although the degree of compliance could affect the reported effectiveness of the interventions, our results reflect and can be generalized to situations under the constraint of limited resources. Second, the multiplicity of outcome measures could limit the potential to synthesize results. Since most studies usually include a number of interventions, it is difficult to sort out the independent effects of a single intervention component. Third, there is also a potential for misclassification of interventions as most of the studies did not report the routine interventions as a part of the IPC bundles. Fourth, we limited our meta-analysis to all studies that reported MRSA colonization. However, this approach is prone to high heterogeneity across studies due to different outcome definitions, study designs, and intervention components. Although we have grouped interventions into eight categories and performed subgroup analyses to identify the source of heterogeneity, it is still difficult to draw a definitive conclusion. Fifth, we found only two moderate-quality studies, and they provided inconsistent evidence of effectiveness. The low quality of the study affects the internal validity of our review. Last, the possibility of spontaneous decolonization and recolonization could affect the estimate of individual studies, which may impact the estimates of this review. However, the spontaneous decolonization rate is low while recolonization is common in LTCFs. A recent study found that the spontaneous decolonization rate among intensive care unit patients colonized by ESBLE was only $2.5 \%$ [87], while that of MRSA was $4.1 \%$ in LTCFs [88]. On the other hand, the recolonization rate of MRSA is high among nursing home residents. In a randomized, double-blind, placebo-controlled trial, $86 \%$ of decolonized nursing home residents became recolonized with the same pretherapy strain of MRSA at 90 days after study entry [73].

Despite its limitations, our review provides the first comprehensive evidence synthesis of the association between IPC interventions and MDRO colonization and infections in LTCFs. Infection prevention and control interventions in LTCFs play an important role in reducing the spread of MDROs across hospitals and community settings. Yet, significant gaps and inconsistencies in current practices are evident. Methodologically less rigorous studies tend to overestimate the effects of IPC programmes, which poses a high risk of bias on the current guidelines and hinders decision-making in public health policies. More rigorously controlled studies are required to answer several key questions: (i) What are the most effective interventions in reducing MDROrelated colonization and infections in LTCFs-in terms of their ideal composition (single-component or multifaceted)?; (ii) What are the institutional and infrastructural determinants for an effective IPC programme? For example, staff-to-resident ratios, bed occupancy, the density of hand washing/rubbing points, etc.?; (iii) What are the short- and long-term intervention adherence from the staff in LTCFs?; and (iv) How does the intervention adherence affect the effectiveness of programmes?

Till we have the answers to these questions, in the absence of a clear benefit from interventions and the presence of evidence that various adverse outcomes linked with decolonization and barrier precautions, basic standard precautions-which generally include 
hand hygiene, environmental cleaning, and staff education that are low-cost and not menacing to residentsremains the optimal approach in LTCFs. Since the success of a programme rests with high institutional compliance [89], reinforcing strict adherence should be the primary strategy to maximize the effects of standard precautions. An engaged administration with clearly defined goals promotes compliance through consultations with frontline staff and adequate resource allocation. It helps to identify and remove implementation barriers for routine standard precautions. Facility managers have to judiciously evaluate the benefits and risks of interventions that have potential negative impacts on residents. When the benefits to residents outweigh the risks, a detailed execution plan should be constructed, predominately when and on what criteria to discontinue the interventions. The possibility of not placing residents with these interventions should always be considered before other options.

\section{Conclusions}

The proliferation of AMR limits treatment options for patients and is no longer adequately addressed solely by research and development of new antibiotics. Apart from curtailing inappropriate use of antibiotics, IPC interventions are rational steps in reducing the colonization and infection risks. However, existing evidence suggested IPC interventions without administrative engagement offer little effect on MDRO control in long-term care settings. Securing the administrative commitment, LTCFs can reinforce the standard precautions in routine care of residents and weigh carefully before applying barrier precautions and decolonization. Prospective studies can explore how strategies promoting prudent use of antibiotics, for instance, antimicrobial stewardship programmes and point-of-care testing, can work hand in hand with the refined IPC strategies to formulate a comprehensive programme in LTCFs.

\footnotetext{
Abbreviations

AE: Administrative engagement; AMR: Antimicrobial resistance; BP: Barrier precautions; C.diff.: Clostridium difficile; Cl: Confidence intervals; CIP-R: Ciprofloxacin-resistant; CRE: Carbapenem-resistant Enterobacteriaceae; CTZ-R: Ceftazidime-resistant; DC: Decolonization; EC: Environmental cleaning; ED: Education; GNB: Gram-negative bacteria; HH: Hand hygiene; HR: Hazard ratio; IPC: Infection prevention and control; KOK: Kin On Kwok; LTCF: Long-term care facility; MDR: Multidrug-resistant; MDRO: Multidrug-resistant organism; MRSA: Methicillin-resistant Staphylococcus aureus; P: P-value; PI: Performance improvement; PRISMA: Preferred reporting items for systematic reviews and meta-analyses; pRR: Pooled risk ratios; RCT: Randomized controlled trial; ROB2: Revised Cochrane risk-of-bias; ROBINS-I: Cochrane risk of bias in nonrandomized studies of interventions; RR: Risk ratios; SC: Source control; SSTI: Skin and soft tissue infection; UC: Usual care; UTI: Urinary tract infection; VRE: Vancomycin-resistant Enterococci; VW: Valerie Wing Yu Wong; YH: Ying Huang.
}

\section{Supplementary Information}

The online version contains supplementary material available at https://doi. org/10.1186/s13756-021-01044-0.

Additional file 1. Search strategies.

Additional file 2. Description of infection prevention and control strategies.

Additional file 3. Interventions included in each studies.

Additional file 4. Characteristics of included studies.

Additional file 5. Forest plot for studies evaluating MRSA colonization.

Additional file 6. Forest plot for sensitivity analysis.

Additional file 7. Risk of bias assessment for randomized trials using Cochrane risk-of-bias tool.

Additional file 8. Risk of bias assessment for non-randomized intervention studies using Cochrane risk of bias in non-randomized studies of intervention tool.

Additional file 9. Contour-enhanced funnel plot of studies.

\section{Acknowledgements}

KOK acknowledges support from Health and Medical Research Fund (Reference Numbers: INF-CUHK-1, COVID1903008-Project D, 17160302, 18170312), General Research Fund (Reference Numbers: 14112818, 24104920), Wellcome Trust Fund (United Kingdom, 200861/Z/16/Z), and Group Research Scheme of The Chinese University of Hong Kong.

\section{Authors' contributions}

KOK and VW wrote the manuscript. KOK, VW, SYSW and WIW conceptualized the study, VW and HY collected and analyzed data, and approved the final version. KOK contributed to the funding of the research. All authors read and approved the final manuscript.

\section{Funding}

The Commissioned Health and Medical Research Fund of the Food and Health Bureau of Hong Kong Special Administrative Region Government supports this study (reference number: CID-CUHK-A).

\section{Availability of data and materials}

This review was based on data extracted from published papers available in the public domain.

\section{Declarations}

Ethics approval and consent to participate

Not applicable.

Consent for publication

Not applicable.

\section{Competing interests}

The authors declare that they have no competing interests.

\section{Author details}

${ }^{1} \mathrm{JC}$ School of Public Health and Primary Care, The Chinese University of Hong Kong, Room 419, 4/F, JC School of Public Health and Primary Care Building, Prince of Wales Hospital, Shatin, N.T., Hong Kong Special Administrative Region, China. ${ }^{2}$ Stanley Ho Centre for Emerging Infectious Diseases, The Chinese University of Hong Kong, Shatin, N.T., Hong Kong Special Administrative Region, China. ${ }^{3}$ Shenzhen Research Institute of The Chinese University of Hong Kong, Shenzhen, China. ${ }^{4}$ Hong Kong Institute of Asia-Pacific Studies, The Chinese University of Hong Kong, Shatin, N.T., Hong Kong Special Administrative Region, China.

Received: 17 December 2020 Accepted: 23 December 2021

Published online: 15 January 2022 


\section{References}

1. Interagency coordination group on antimicrobial resistance (IACG). No time to wait: securing the future from drug-resistant infections. United Nations Foundation for the IACG; 2019

2. Balsells E, Shi T, Leese C, Lyell I, Burrows J, Wiuff C, et al. Global burden of Clostridium difficile infections: a systematic review and meta-analysis. J Glob Health. 2019;9(1):010407.

3. Jonas OB, Irwin A, Berthe FCJ, Le Gall FG, Marquez PV. Final report: drug resistant infections - a threat to our economic future. Washington D.C.: World Bank Group. http://documents.worldbank.org/curated/en/32331 1493396993758/final-report.

4. Su CH, Chang SC, Yan JJ, Tseng SH, Chien LJ, Fang CT. Excess mortality and long-term disability from healthcare-associated Staphylococcus aureus infections: a population-based matched cohort study. PLOS ONE. 2013;8:e71055.

5. Chen H, Branch IC, Centre for Health Protection, Department of Health, Kong $\mathrm{H}$, Au KM, et al. Multidrug-resistant organism carriage among residents from residential care homes for the elderly in Hong Kong: a prevalence survey with stratified cluster sampling. Hong Kong Med J. 2018;24(4):350-60.

6. Cheng VCC, Chen JHK, Ng WC, Wong JYH, Chow DMK, Law TC, et al. Emergence of carbapenem-resistant Acinetobacter baumannii in nursing homes with high background rates of MRSA colonization. Infect Control Hosp Epidemiol. 2016;37:983-6.

7. Jeong $\mathrm{H}, \mathrm{Kang} \mathrm{S}, \mathrm{Cho} \mathrm{HJ}$. Prevalence of multidrug-resistant organisms and risk factors for carriage among patients transferred from long-term care facilities. Infect Chemother. 2020;52:183-93.

8. Cassone M, Mody L. Colonization with multi-drug resistant organisms in nursing homes: scope, importance, and management. Curr Geriatr Rep. 2015;4:87-95

9. Mody L, Bradley SF, Huang SS. Keeping the "home" in nursing home: implications for infection prevention. JAMA Intern Med. 2013;173:853-4.

10. Bowen ME, Craighead JD, Angelina Klanchar S, Nieves-Garcia V. Multidrug-resistant organisms in a community living facility: tracking patient interactions and time spent in common areas. Am J Infect Control. 2012:40(7):677-9.

11. Rodríguez-Villodres Á, Martín-Gandul C, Peñalva G, Guisado-Gil AB, Crespo-Rivas JC, Pachón-Ibáñez ME, et al. Prevalence and risk factors for multidrug-resistant organisms colonization in long-term care facilities around the world: a review. Antibiotics (Basel). 2021;10(6):680

12. Lee BY, Bartsch SM, Wong KF, Singh A, Avery TR, Kim DS, et al. The impor tance of nursing homes in the spread of methicillin-resistant Staphylococcus aureus (MRSA) among hospitals. Med Care. 2013;51:205-15.

13. Briggs R, Coughlan T, Collins R, O'Neill D, Kennelly SP. Nursing home residents attending the emergency department: clinical characteristics and outcomes. QJM. 2013;106:803-8.

14. Barnes SL, Harris AD, Golden BL, Wasil EA, Furuno JP. Contribution of interfacility patient movement to overall methicillin-resistant Staphylococcus aureus prevalence levels. Infect Control Hosp Epidemiol. 2011:32:1073-8.

15. Cock I, Cheesman M, llanko A, Blonk B. Developing new antimicrobial therapies: are synergistic combinations of plant extracts/compounds with conventional antibiotics the solution? Pharmacogn Rev. 2017;11:57.

16. Bell BG, Schellevis F, Stobberingh $E_{1}$ Goossens $H$, Pringle M. A systematic review and meta-analysis of the effects of antibiotic consumption on antibiotic resistance. BMC Infect Dis. 2014;14:13.

17. Holmes AH, Moore LSP, Sundsfjord A, Steinbakk M, Regmi S, Karkey A, et al. Understanding the mechanisms and drivers of antimicrobial resistance. Lancet. 2016:387:176-87.

18. Abbas S, Stevens M. Chapter 14 Horizontal vs vertical infection control strategies. In: Bearman GML, Steven M, Edmond MB, Wenzel RP, editors. Guide to infection control in the hospital. 5th ed. Boston, MA: International Society for Infectious Diseases; 2014. https://www.dspsv.ro/uploa ds/epidemiologie/5thEd_GuidelnfectionControl_forWEB.pdf.

19. Eikelenboom-Boskamp A, Haaijman J, Bos M, Saris K, Poot E, Voss A, et al. Dutch guideline for preventing nosocomial transmission of highlyresistant micro-organisms (HRMO) in long-term care facilities (LTCFs). Antimicrob Resist Infect Control. 2019;8:146.

20. Hospital Infection Control Practices Advisory Committee (HICPAC). Recommendations for preventing the spread of vancomycin resistance. Infect Control Hosp Epidemiol. 1995:16:105-13.
21. Wisconsin Healthcare-Associated Infections (HAl) Prevention Program. Guidelines for prevention and control of antibiotic resistant organisms in health care settings. Wisconsin: Wisconsin Division of Public Health, Bureau of Communicable Diseases; 2005.

22. Henderson A, Nimmo GR. Control of healthcare- and communityassociated MRSA: recent progress and persisting challenges. Br Med Bull. 2018;125:25-41.

23. Giannella M, Tedeschi S, Bartoletti M, Viale P. Prevention of infections in nursing homes: antibiotic prophylaxis versus infection control and antimicrobial stewardship measures. Expert Rev Anti Infect Ther. 2016;14:219-30.

24. Dumyati G, Stone ND, Nace DA, Crnich CJ, Jump RLP. Challenges and strategies for prevention of multidrug-resistant organism transmission in nursing homes. Curr Infect Dis Rep. 2017;19:18.

25. Tomczyk S, Zanichelli V, Lindsay Grayson M, Twyman A, Abbas M, Pires D, et al. Control of carbapenem-resistant Enterobacteriaceae, Acinetobacter baumannii, and Pseudomonas aeruginosa in healthcare facilities: a systematic review and reanalysis of quasi-experimental studies. Clin Infect Dis. 2019;68(5):873-84.

26. Teerawattanapong N, Kengkla K, Dilokthornsakul P, Saokaew S, Apisarnthanarak A, Chaiyakunapruk N. Prevention and control of multidrug-resistant gram-negative bacteria in adult intensive care units: a systematic review and network meta-analysis. Clin Infect Dis. 2017;64(suppl_2):S51-60.

27. Hughes C, Tunney M, Bradley MC. Infection control strategies for preventing the transmission of meticillin-resistant Staphylococcus aureus (MRSA) in nursing homes for older people. Cochrane Database Syst Rev. 2013;11:CD00354

28. Baldwin NS, Gilpin DF, Tunney MM, Kearney MP, Crymble L, Cardwell C, et al. Cluster randomised controlled trial of an infection control education and training intervention programme focusing on meticillin-resistant Staphylococcus aureus in nursing homes for older people. J Hosp Infect. 2010;76:36-41.

29. Lee MH, Lee GA, Lee SH, Park Y-H. Effectiveness and core components of infection prevention and control programmes in long-term care facilities: a systematic review. J Hosp Infect. 2019;102:377-93.

30. Uchida M, Pogorzelska-Maziarz M, Smith PW, Larson E. Infection prevention in long-term care: a systematic review of randomized and nonrandomized trials. J Am Geriatr Soc. 2013;61:602-14.

31. Moher D, Liberati A, Tetzlaff J, Altman DG, for the PRISMA Group. Preferred reporting items for systematic reviews and meta-analyses: the PRISMA statement. BMJ. 2009:339:b3535.

32. Siegel JD, Rhinehart $E$, Jackson M, Chiarello L, Healthcare Infection Control Practices Advisory Committee. Management of multidrugresistant organisms in health care settings, 2006. Am J Infect Control. 2007;35:S165-93.

33. European Centre for Disease Prevention and Control. European surveillance of clostridioides (clostridium) difficile infections surveillance-protocol version 2.4. Stockholm: ECDC; 2019.

34. Higgins JPT, Altman DG, Gøtzsche PC, Jüni P. The Cochrane Collaboration's tool for assessing risk of bias in randomised trials. BMJ. 2011;343:d5928.

35. Sterne JAC, Hernán MA, Reeves BC, Savović J, Berkman ND, Viswanathan $M$, et al. ROBINS-I: a tool for assessing risk of bias in non-randomised studies of interventions. BMJ. 2016:355:i4919.

36. McGuinness LA, Higgins JPT. Risk-of-bias visualization (robvis): an R package and shiny web app for visualizing risk-of-bias assessments. Res Syn Meth. 2020;20:7.

37. Sterne JAC, Sutton AJ, loannidis JPA, Terrin N, Jones DR, Lau J, et al. Recommendations for examining and interpreting funnel plot asymmetry in meta-analyses of randomised controlled trials. BMJ. 2011;343:d4002.

38. Egger M, Davey Smith G, Schneider M, Minder C. Bias in meta-analysis detected by a simple, graphical test. BMJ. 1997;315:629-34.

39. Higgins JPT, Green S. Recommendations on testing for funnel plot asymmetry. In: Cochrane handbook for systematic reviews of interventions version; 2011. p. 5.

40. Metcalf B, Henley W, Wilkin T. Effectiveness of intervention on physical activity of children: systematic review and meta-analysis of controlled trials with objectively measured outcomes. BMJ. 2012;345:e5888. 
41. Cugelman B, Thelwall M, Dawes P. Online interventions for social marketing health behavior change campaigns: a meta-analysis of psychological architectures and adherence factors. J Med Internet Res. 2011;13:e17.

42. R: A language and environment for statistical computing [program]. Vienna: R Foundation for Statistical Computing; 2020.

43. Viechtbauer W. Conducting meta-analyses in $\mathrm{R}$ with the metafor package J Stat Softw UCLA Stat. 2010;36:1-48

44. Bellini C, Petignat C, Masserey E, Büla C, Burnand B, Rousson V, et al. Universal screening and decolonization for control of MRSA in nursing homes: a cluster randomized controlled study. Infect Control Hosp Epidemiol. 2015;36:401-8.

45. Ben-David D, Masarwa S, Fallach N, Temkin E, Solter E, Carmeli Y, et al. Success of a national intervention in controlling carbapenem-resistant Enterobacteriaceae in Israel's long-term care facilities. Clin Infect Dis. 2019;68:964-71.

46. Bowler WA, Bresnahan J, Bradfish A, Fernandez C. An integrated approach to methicillin-resistant Staphylococcus aureus control in a rural, regional-referral healthcare setting. Infect Control Hosp Epidemiol. 2010;31:269-75.

47. Chuang VW, Tsang $\mid \mathrm{H}$, Keung JP, Leung JY, Yuk JM, Wong DK, et al. Infection control intervention on meticillin resistant Staphylococcus aureus transmission in residential care homes for the elderly. J Infect Prev. 2015;16:58-66.

48. Héquet D, Rousson V, Blanc DS, Büla C, Qalla-Widmer L, Masserey E, et al. Universal screening and decolonization for control of MRSA in nursing homes: follow-up of a cluster randomized controlled trial. J Hosp Infect. 2017;96:69-71.

49. Ho ML, Seto WH, Wong LC, Wong TY. Effectiveness of multifaceted hand hygiene interventions in long-term care facilities in Hong Kong: a cluster-randomized controlled trial. Infect Control Hosp Epidemiol. 2012:33:761-7.

50. Horner C, Wilcox M, Barr B, Hall D, Hodgson G, Parnell P, et al. The longitudinal prevalence of MRSA in care home residents and the effectiveness of improving infection prevention knowledge and practice on colonisation using a stepped wedge study design. BMJ Open. 2012;2:e000423.

51. Jaqua-Stewart MJ, Tjaden J, Humphreys DW, Bade P, Tille PM, Peterson KG, et al. Reduction in methicillin-resistant Staphylococcus aureus infection rate in a nursing home by aggressive containment strategies. S D J Med. 1999;52:241-7.

52. Kauffman CA, Terpenning MS, He X, Zarins LT, Ramsey MA, Jorgensen KA, et al. Attempts to eradicate methicillin-resistant Staphylococcus aureus from a long-term-care facility with the use of mupirocin ointment. Am J Med. 1993;94:371-8.

53. Mody L, Krein SL, Saint S, Min LC, Montoya A, Lansing B, et al. A targeted infection prevention intervention in nursing home residents with indwelling devices: a randomized clinical trial. JAMA Intern Med. 2015; 175:714-23.

54. Morgan DJ, Zhan M, Goto M, Franciscus C, Alexander B, Vaughan-Sarrazin $M$, et al. The effectiveness of contact precautions on methicillin-resistant Staphylococcus aureus (MRSA) in long-term care across the United States. Clin Infect Dis. 2020;71(7):1676-83.

55. Ostrowsky BE, Trick WE, Sohn AH, Quirk SB, Holt S, Carson LA, et al. Control of vancomycin-resistant Enterococcus in health care facilities in a region. N Engl J Med. 2001;344:1427-33.

56. Peterson LR, Boehm S, Beaumont JL, Patel PA, Schora DM, Peterson KE, et al. Reduction of methicillin-resistant Staphylococcus aureus infection in long-term care is possible while maintaining patient socialization: a prospective randomized clinical trial. Am J Infect Control. 2016;44:1622-7.

57. Schora DM, Boehm S, Das S, Patel PA, O'Brien J, Hines C, et al. Impact of detection, education, research and decolonization without isolation in long-term care (DERAIL) on methicillin-resistant Staphylococcus aureus colonization and transmission at 3 long-term care facilities. Am J Infect Control. 2014;42:S269-73.

58. Silverblatt FJ, Tibert C, Mikolich D, Blazek-D’Arezzo J, Alves J, Tack M, et al. Preventing the spread of vancomycin-resistant enterococci in a longterm care facility. J Am Geriatr Soc. 2000;48:1211-5.

59. Singh MB, Evans ME, Simbartl LA, Kralovic SM, Roselle GA. Evaluating the effect of a Clostridium difficile infection prevention initiative in veterans health administration long-term care facilities. Infect Control Hosp Epidemiol. 2018;39:343-5.
60. Thomas JC, Bridge J, Waterman S, Vogt J, Kilman L, Hancock G. Transmission and control of methicillin-resistant Staphylococcus aureus in a skilled nursing facility. Infect Control Hosp Epidemiol. 1989;10:106-10.

61. Schweon SJ, Edmonds SL, Kirk J, Rowland DY, Acosta C. Effectiveness of a comprehensive hand hygiene program for reduction of infection rates in a long-term care facility. Am J Infect Control. 2013;41:39-44.

62. Clock SA, Cohen B, Behta M, Ross B, Larson EL. Contact precautions for multidrug-resistant organisms: current recommendations and actual practice. Am J Infect Control. 2010;38:105-11.

63. Muto CA, Jernigan JA, Ostrowsky BE, Richet HM, Jarvis WR, Boyce JM, et al. SHEA guideline for preventing nosocomial transmission of multidrugresistant strains of Staphylococcus aureus and enterococcus. Infect Control Hosp Epidemiol. 2003;24:362-86.

64. Huskins WC, Charles Huskins W, Huckabee CM, O'Grady NP, Murray P, Kopetskie $H$, et al. Intervention to reduce transmission of resistant bacteria in intensive care. Surv Anesthesiol. 2011;364(15):1407-18.

65. Marra AR, Edmond MB, Schweizer ML, Ryan GW, Diekema DJ. Discontinuing contact precautions for multidrug-resistant organisms: a systematic literature review and meta-analysis. Am J Infect Control. 2018;46:333-40.

66. Barker AK, Brown K, Siraj D, Ahsan M, Sengupta S, Safdar N. Barriers and facilitators to infection control at a hospital in northern India: a qualitative study. Antimicrob Resist Infect Control. 2017;6:35.

67. Dhar S, Marchaim D, Tansek R, Chopra T, Yousuf A, Bhargava A, et al. Contact precautions: more is not necessarily better. Infect Control Hosp Epidemiol. 2014;35:213-21.

68. Stelfox HT, Bates DW, Redelmeier DA. Safety of patients isolated for infection control. JAMA. 2003;290:1899-905.

69. Morgan DJ, Diekema DJ, Sepkowitz K, Perencevich EN. Adverse outcomes associated with contact precautions: a review of the literature. Am J Infect Control. 2009;37:85-93.

70. Seibert G, Ewers T, Barker AK, Slavick A, Wright M-O, Stevens L, et al. What do visitors know and how do they feel about contact precautions? Am J Infect Control. 2018:46:115-7.

71. Tang J, Hui J, Ma J, Mingquan C. Nasal decolonization of Staphylococcus aureus and the risk of surgical site infection after surgery: a meta-analysis. Ann Clin Microbiol Antimicrob. 2020;19:33.

72. Holton DL, Nicolle LE, Diley D, Bernstein K. Efficacy of mupirocin nasal ointment in eradicating Staphylococcus aureus nasal carriage in chronic haemodialysis patients. J Hosp Infect. 1991;17:133-7.

73. Mody L, Kauffman CA, McNeil SA. Mupirocin-based decolonization of Staphylococcus aureus carriers in residents of 2 long-term care facilities: a randomized, double-blind, placebo-controlled trial. Clin Infect Dis. 2003;37(11):1467-74.

74. Mody L, Gibson KE, Horcher A, Prenovost K, McNamara SE, Foxman B, et al. Prevalence of and risk factors for multidrug-resistant Acinetobacter baumannii colonization among high-risk nursing home residents. Infect Control Hosp Epidemiol. 2015;36:1155-62.

75. Simor AE, Phillips E, McGeer A, Konvalinka A, Loeb M, Devlin HR, et al. Randomized controlled trial of chlorhexidine gluconate for washing, intranasal mupirocin, and rifampin and doxycycline versus no treatment for the eradication of methicillin-resistant Staphylococcus aureus colonization. Clin Infect Dis. 2007;44:178-85.

76. Mattingly AS, Starr N, Bitew S, Forrester JA, Negussie T, Bereknyei Merrell $S$, et al. Qualitative outcomes of clean cut: implementation lessons from reducing surgical infections in Ethiopia. BMC Health Serv Res. 2019;19:579.

77. Apisarnthanarak A, Weber DJ. Environmental cleaning in resource-limited settings. Curr Treat Options Infect Dis. 2018;10:48-54

78. Sinkowitz-Cochran RL, Burkitt KH, Cuerdon T, Harrison C, Gao S, Scott Obrosky D, et al. The associations between organizational culture and knowledge, attitudes, and practices in a multicenter Veterans Affairs quality improvement initiative to prevent methicillin-resistant Staphylococcus aureus. Am J Infect Control. 2012;40:138-43.

79. Rosenstock IM. Historical origins of the health belief model. Health Educ Monogr. 1974;2:328-35.

80. Rosenstock IM. The health belief model and personal health behavior. Becker MH, editor. Slack, Thorofare, NJ: C. B. Slack; 1974.

81. Atwood MA, Mora JW, Kaplan AW. Learning to lead: evaluating leadership and organizational learning. Leadersh Organ Dev J. 2010;31:576-95. 
82. Resar R, Griffin FA, Haraden C, Nolan TW. Using care bundles to improve health care quality. IHI innovation series white paper. Cambridge: Institute for Healthcare Improvement; 2012. 2014.

83. Mody L, Gontjes KJ, Cassone M, Gibson KE, Lansing BJ, Mantey J, et al. Effectiveness of a multicomponent intervention to reduce multidrugresistant organisms in nursing homes: a cluster randomized clinical trial. JAMA Netw Open. 2021:4:e2116555.

84. National Health and Medical Research Council. Australian Guidelines for the Prevention and Control of Infection in Healthcare-2010. NHMRC, National Health \& Medical Research Council; 2010.

85. Tang A, Kwok KO, Wei VWI, Chen H, Park W-H, Wong SYS, et al. Synergistic effect of combination interventions for methicillin-resistant staphylococcus aureus transmission control in nursing homes: a computation modelling evaluation with heterogeneous contact mixing.

86. Barker AK, Scaria E, Safdar N, Alagoz O. Evaluation of the cost-effectiveness of infection control strategies to reduce hospital-onset Clostridioides difficile infection. JAMA Netw Open. 2020;3:e2012522.

87. Duployez C, Wallet F, Rouzé A, Nseir S, Kipnis E, El Kalioubie A, et al. Spontaneous decolonization during hospitalization in intensive care unit patients colonized by extended-spectrum beta-lactamase-producing Enterobacterales. J Hosp Infect. 2020;106:500-3.

88. Feingold K, Siegler EL, Wu B, Stevenson C, Kirk K, Jedrziewski MK. Methicillin-resistant Staphylococcus aureus colonization in a new nursing home. Aging. 1994;6:368-71.

89. Pittet D. Compliance with hand disinfection and its impact on hospitalacquired infections. J Hosp Infect. 2001;48(Suppl A):S40-6.

\section{Publisher's Note}

Springer Nature remains neutral with regard to jurisdictional claims in published maps and institutional affiliations.

- fast, convenient online submission

- thorough peer review by experienced researchers in your field

- rapid publication on acceptance

- support for research data, including large and complex data types

- gold Open Access which fosters wider collaboration and increased citations

- maximum visibility for your research: over 100M website views per year

At BMC, research is always in progress.

Learn more biomedcentral.com/submissions 